\title{
Better Citizens through Better Living: Consumer Culture and Corporate Capital in Employee Communications and Public Relations at Du Pont Chemical, 1945-1960
}

\author{
Steven T. Sheehan
}

In the months leading up to the 2000 U.S. presidential election, the Business Industry Political Action Committee (BIPAC) developed the Prosperity Project. As the project's website proclaims, the program has launched a "grassroots" campaign to help "companies and associations achieve their public policy goals" ("Prosperity Project"). Essentially, the Prosperity Project works with participating companies to provide resources and technical assistance, so that management can register employees to vote and urge them to choose candidates who would support the company's interests. The project operates a website and distributes CDs packed with pro-business voter education materials. State and local Prosperity Projects, run by trade associations, piggyback on the national campaign, tailoring material to make it suitable for particular industries and to address relevant state and local political issues. By the 2006 midterm elections, the national project catered directly to over 900 participating companies and had established several dozen state and local programs (Genzer). It continues to operate in 2010. While media coverage of the Prosperity Project presented this effort to mobilize an army of pro-business employee voters as a novel campaign, BIPAC has simply put digital-age packag-

Steven T. Sheehan is Associate Professor of History at University of Wisconsin-Fox Valley. His work on mid-twentieth-century consumer culture has appeared in such venues as The Journal of Popular Culture and American Studies. He is currently working on a book exploring the importance of Franklin Roosevelt's Fireside Chats to American political culture. 
ing on a public relations product first developed in the late 1940s to attack union culture and the New Deal state.

Executives at E. I. du Pont de Nemours \& Co. (Du Pont) dedicated much of their public relations program toward influencing the politics of rank-and-file employees during the decades following World War II. Rather than websites and CDs, the company's public relations department used a glossy house publication as the centerpiece of its efforts. The employee magazine, called Better Living, sold a vision of the good life, unique to postwar America. A brief editorial that appeared in the magazine's fourth issue summarized the major themes that dominated the magazine throughout the first fifteen years of its existence. The editorial detailed a conversation between the magazine's editor and a friend, a "notorious needler" whose "approach to life" the editor found "disconcerting." The friend had asked the editor to explain the phrase "better living."

"What do you mean, better living?" he asked. "Better than what? Better than when? 'Better' is a comparative adjective; it's got to be related to something."

Well it's true that "better" implies a degree of progress over something that existed before. It presumes that what you started with has been improved. And we were glad to accept our friend's challenge to reply "Better Than Ever Before" and "Better Than Anywhere Else."

In the ensuing extrapolation of his answer, the editor drew favorable comparisons between the material comforts and consumer commodities enjoyed by mid-twentieth century Americans and what had been available to people a century before and between the material lives of contemporary U.S. citizens and those of other nations, particularly the Soviet Union. The editor then moved beyond matters of simple definition to explore the reasons behind the current elevated American living standard. He argued, "every American worker is backed by a large investment of cash money, contributed by other Americans, which puts into his hands the marvelously efficient tools of modern industry" ("What Is 'Better Living?"”).

In hundreds of pictorial essays published in the magazine from 1946 to the early 1960s, the editors showed Du Pont employees that they, and in fact all of America's workers, enjoyed a living standard far better than American workers had enjoyed in the past and far better than their contemporaries in other nations. Better Living let Du Pont workers know that they were indeed citizens of what historian Lizabeth Cohen has labeled a "consumers' republic," a nation in which millions of workers and their families held liberty within and exercised sovereignty over the American political economy. The magazine repeatedly argued that corporate capitalism was the source of material abundance. Only the profit motive, and massive corporate profits, could generate the capital — or to use the magazine's term the "industrial capacity" - that streamlined production and filled markets with inexpensive, quality goods. American workers could best contribute to this national mission by standing back and letting the wheels of capital turn smoothly, rather than pushing for govern- 
ment regulation of industry, insisting on cumbersome schemes of social democracy, or engaging in labor strife. By working hard, consuming the abundance American capitalism provided, and helping to keep the state out of private business affairs, working-class Americans would fulfill their duties as citizens of, and continue to enjoy the comforts of, the consumers' republic.

In his examination of American industrial relations in the 1940s, Howell John Harris has broadly described what he terms a postwar "Communications in Industry" campaign in which corporate executives sought to "build correct attitudes toward work and managerial authority" among employees and a "Great Free Enterprise Campaign" in which they influenced public opinion about economic policy through the mass media. Harris notes that these campaigns sometimes overlapped (189195). This essay offers a detailed analysis of the efforts of one the leaders in this campaign to capture the hearts and minds of industrial workers and the general public. While business and labor historians have come to label this style of attack on unions "Boulwarism" - in honor of its most famous practitioner, General Electric Vice President Lemuel Boulware-we should not ignore the pioneering role that Du Pont executives played in this postwar information campaign.

Du Pont management and public relations staff made no distinction between employees and the public. Indeed, they spoke to their labor force as an important "public." Public relations professionals often divide their audiences into numerous "publics." According to that professional logic, a public is a group of individuals who share a self-identifying characteristic and some common interest. That group will develop a shared opinion of an organization, which when expressed, can affect the well-being of the institution. Thus, Du Pont management saw their labor force not only as individuals who affected the company through direct contributions of labor, but more importantly, as a public that shaped the company's, the broader business community's, and the nation's past, present, and future as working-class citizen consumers. They consciously wedded personnel policies to public relations in an effort to mold citizens who saw themselves as a component of a larger national project of "better living."

This examination of postwar Du Pont also sheds light on the rise of American conservatism in the late twentieth century. While scholars have written a number of accounts tracing the popular origins of contemporary conservatism in movements resisting the changes wrought by Civil Rights and feminism in the 1960s and 1970s, we have only recently begun to examine the intellectual origins of this conservative movement. ${ }^{1}$ An examination of Du Pont's employee and public relations helps to highlight the development of conservative leadership and thought in the early postwar era. The social history of contemporary American conservatism may have started on the streets and in the family rooms of Boston, Birmingham, and Orange County in the 1960s. Its intellectual and cultural history began over a decade earlier at the typewriters and in the boardrooms of a corporate intelligentsia. As Kim Philips-Fein has adeptly argued, contemporary conservatism finds its genesis not only in reactions to racial and gender transformation, but in the attack on labor, the New Deal state, and "creeping socialism" in the 1940s and 1950s.

My analysis focuses on the campaigns that executives and public relations 
experts mounted to shape the way Americans perceived class and consumption in the postwar period. I do not purport that working-class Americans accepted this ideology wholeheartedly. Yet I also avoid the tendency of many historians to dismiss the claims of business leaders and culture producers about the democratic nature of consumption as so much hyperbole or propaganda. As Howell John Harris, Elizabeth Fones-Wolf, and Sanford Jacoby have demonstrated in their studies of postwar labor and public relations, the postwar business community mounted powerful campaigns to shape ideas about the political economy and public policy regarding labor and social democratic agendas. To borrow Harris's terminology, that campaign shaped the "environment" in which all discussions of labor and public policy took place. My study demonstrates that the language adopted by business public relations in the 1940s and 1950s helped to establish a framework within which discussions of class, consumption, and citizenship proceeded. Thus, this study demonstrates the power of business's information campaigns, if not to directly convince American citizens to agree with all of its prerogatives, then at least to establish a frame of economic and political understanding in which discussions took place.

\section{From Merchant of Death to Better Living-Public and Employee Relations at Du Pont in the Twentieth Century}

Du Pont began its history in 1802, when Irenee du Pont established a black powder factory along the Brandywine River in northern Delaware. ${ }^{2}$ The explosives firm experienced several growth spurts in the nineteenth century, supplying the federal government with munitions during the War of 1812, the Mexican-American War, and the Civil War. World War I marked a watershed in company history. The company manufactured $40 \%$ of the explosives used by the allies during the war. Its capital assets increased from $\$ 83$ million to $\$ 308$ million between 1914 and 1917. Total employment at the company soared from 5,500 to 85,000 during the same time period (Phelan and Pozen 18-19). Wanting to take advantage of the tremendous increase in productive capacity, executives committed to a policy of product diversification. By the 1930s, Du Pont was no longer simply an explosives manufacturer, but the world's largest chemical processor developing and manufacturing such products as cellophane, neoprene rubber, Lucite paint, Duco car finishes, rayon, and nylon (Hounshell and Smith).

World War I also left Du Pont with a severe image problem. In September 1934, the US Senate convened a special committee, chaired by Gerald Nye of North Dakota, to investigate the role munitions makers played in destabilizing international relations before the war. Nye named Du Pont as one of the largest American arms makers and called company executives before the committee to answer hostile questions about its dealings in World War I. Although the committee found no criminal involvement on Du Pont's part, the investigation did uncover "a long list of abuses, ranging from unscrupulous methods in the promotion of foreign munitions sales to stimulating arms competition and obstructing peace efforts" (Stone 267). Thus, just as Du Pont shifted much of its manufacturing capacity away from explosives to other chemical products, it found itself labeled a "Merchant of Death" that not only profited from arms sales during World War I, but also currently sold arms to 
Germany and destabilized international peace in hopes of another war windfall (Wilz).

Given the "Merchant of Death" charge and the general disdain in which increasing numbers of Americans held big business and corporations as the economy sank into the Great Depression, executives at Du Pont - and many other large U.S. companies - began to mount a sustained public relations effort in the 1930s. In 1935, the company established its Publicity Department (it was renamed

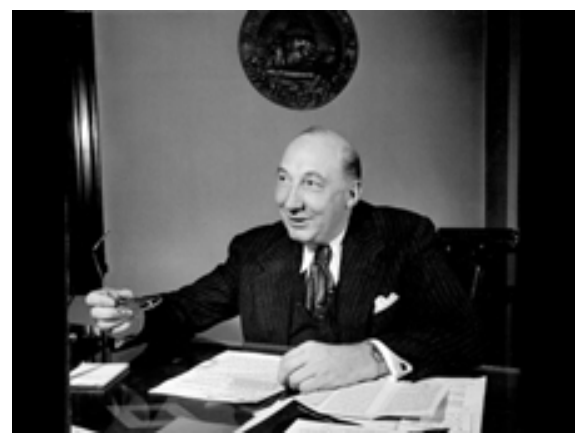

Figure 1. Harold Brayman. Courtesy of the Hagley Museum and Library, Wilmington, DE the "Public Relations Department" three years later). Working in concert with the notable advertising firm Batten, Barton, Durstine, and Osborn, Inc., (BBDO), the P. R. Department developed a slogan that would convey the company's mission and role in society_ "Better Things, For Better Living... Through Chemistry." The historian William Bird points out that the Du Pont P. R. Department employed and helped to pioneer the much broader transition to what he calls the "New Vocabulary" of business in the 1930s. Until the 1930s, businessmen had launched outright rhetorical assaults on government regulation and unionism as threats to American free enterprise and business prerogatives. Amid the general anti-big business climate of the 1930s, business interests began to employ more sophisticated, modern public relations techniques. They developed a language stressing the concepts of "more," "new," and "better," that celebrated an American way of life and a utopian future engineered by enterprise and industry. Ultimately, the "New Vocabulary" presented a much more interesting and attractive utopian package to the public than earlier didactic attacks on labor and the New Deal (Bird).

World War II brought another period of rapid government-subsidized economic expansion at Du Pont. Yet this brief interlude as a war supplier did not sway Du Pont from its stated motto of bringing "better living" to the civilian public. Harold Brayman deserves the most credit for bringing the conception of "better living" to its full fruition in the postwar period (see figure 1). Brayman came to the Du Pont P. R. department as an assistant director in 1942 and assumed the directorship in 1944. He reaffirmed the department's breadth of mission. Until his retirement in 1965 , he reiterated that the role of public relations in business was to create a "good general business climate" and to help the public understand "the general economic framework" in which business operated (Brayman, "The Only Way" 5-6).

Interestingly, despite the grandness of that vision, Brayman believed that business interests, including the Du Pont Public Relations Department, should communicate that vision to a relatively narrow constituency. He developed what he called the "precinct system" of public relations. Each business, he argued, strongly influenced a portion of the public, divided into distinct precincts respectively composed of its own employees, suppliers, plant communities, stockholders, and customers. If each individual business spoke directly to its precincts and won 
them over to a positive view of the company and the business system in general, American corporate capital would ultimately win the favor of the entire American public. Brayman believed employees to be the most important precinct, because they had the most direct contact with the company, spoke to the largest secondary audience about the business, and often had the most negatively skewed perceptions of the business world. He argued that the most effective way to convince the employee of the overall positive effect of big business was to appeal to his or her self interest or "to show him where he benefits and not speak in broad generalities about free enterprise" (Brayman, "The Only Way" and "Du Pont Public Relations Department"). In an explanation of the precinct system written for public relations professionals, Brayman argued that a positive view of business "would be greatly to the individual interest of the employees themselves" because "it would assure the continuance of freedom of the American people and the steady increase of the American standard of living which sets us apart from the rest of the world" (Brayman, "The Only Way" 5). Thus, Du Pont's postwar public relations policy hinged on the company's employees, who needed to accept the idea of a superior and uniquely American standard of living and to link their own living standards to the welfare of Du Pont and corporate capitalism in general.

Brayman's precinct approach and appeal to employee self-interest was representative of a much wider shift in public relations strategy following World War II in which public relations professionals in America began to actively address workers as a crucial, even the most important, "public" to which business should speak. Before the war, when executives addressed workers, they did so almost exclusively as employees. Prewar welfare capitalists offered and highlighted generous wages and benefits, as did postwar Du Pont; however, their information campaigns generally sought to build employee loyalty and morale by making the worker feel part of a company "family" or a plant community. On the rare occasions when employers did address broader political and socioeconomic issues, they did so by celebrating a vague commitment to "free enterprise" and the "American Way of Life" without linking the terms directly to employees' lives. ${ }^{3}$ In the postwar period, executives at companies like Du Pont took up the call of such employee communications experts as Robert Newcomb to "speak up" to their workers about economic and political issues. In his 1951 manifesto titled Speak Up, Management!, Newcomb encapsulated this growing interest in the employee as a member of a crucial public to which management had direct access:

If the American industrial system is to be preserved in recognizable form, then it must make itself felt upon the employees of America, the people in the mines, the mills, the factories, the offices and other institutions where a person works for pay.

Why communicate? Because if management doesn't get itself known, understood, and liked by a large segment of the voting American public, the democratic system as we know it will yield to a system of controlled economy. 
Management, through these eras of growing crisis, has maintained a silence about itself. While its detractors have hacked away at it, weakening its foundations, management has said nothing. It's getting awfully late. Speak up, management! (16-17)

C. J. Dover, a self-described expert on employee communications who had served in the employee communications program at General Electric, put the issue even more succintly:

The problems causing the gravest concern to $[. .$.$] executives$ all depend upon public understanding for solution-and [...] employees themselves make up a very large part of the general public which, in the final analysis, dictates government policy on these problems. (19-20, [emphasis in original])

Thus, while prewar welfare capitalists sought to build local and apolitical families of workers, postwar corporate public and employee relations professionals looked to forge a politicized workforce that saw itself as part of a broad national public. Following the mobilization of workers by labor liberalism in the 1930s and 1940s, and the continuing public animosity between spokesmen for capital and labor, the time had come for management to win this critical public to the side of corporate capital.

\section{Methods and Readership of Better Living}

On December 6, 1946 the Du Pont Public Relations Department announced the inaugural issue of the company's "pictorial news magazine" scheduled for distribution in company plants and offices beginning the following week. The magazine "proposed to show Du Pont people at their jobs, homes, and recreations" (Press Release). As announced, the magazine appeared in plants in mid-December of 1946. It circulated free of charge to employees at each Du Pont plant, laboratory, and administrative office 6 times per year until 1972, at which time the company discontinued publication. Throughout its run, the magazine employed a full-time editor, and for the majority of the time, the editorial page listed several assistant and associate editors, staff photographers, and a large number of consulting editors from Du Pont's production and administrative departments. The fact that the Public Relations Department published the magazine rather than the Service Department, which handled most employment matters, indicates that the company sought to speak to workers as a "public." That approach manifested itself in the magazine's content which, rather than focusing narrowly on employment issues, offered readers a sweeping vision of their company's and their own places in the American economy and polity.

In Better Living, Du Pont forged what members of the company's Public Relations Department believed to be the perfect format for conveying the company's views on business and economy to their workers. From its outset, editors modeled the publication after contemporary pictorial magazines like Life and Look. The editors assumed that they competed against other popular media and therefore desired a format that not only grabbed the reader's interest, but also made points quickly 
and simply. Brayman argued that the maximum use of pictorials and a spartan use of text constituted the most interesting and therefore the most effective way to communicate information in an employee publication (Brayman, "The Only Way" 6-7). Thus, the magazine employed the technique of the "pictorial essay," using simple charts and graphs, and more importantly posed photographs of Du Pont employees, to make interpretive arguments about American business, economics, and society.

The publishers clearly targeted the magazine at the company's blue-collar personnel. In 1959, William Halley, an employee of the Du Pont Public Relations Department, authored a book that served as a how-to manual for writers and editors of employee publications. Halley acknowledged his debt to the Du Pont PR Department, asserting that "the company's philosophy and practice [were] the essence of the point of view expressed" in his book and that he employed "the ideas of industrial managers and editors" who contributed to Du Pont publications (viii). Throughout the book, Halley cited Du Pont publications, most frequently Better Living, as examples of effective public relations for employees. Thus, his advice to other publishers essentially comprised a restatement of Du Pont's public relations and publications policies. When laying out the goals of employee publications Halley argued that publications should strive to reach those furthest distant, socially as well as geographically, from the central office that published it. The most revealing insight Halley offered into Better Living's intended readership followed his admonishment to "know your audience." Halley recommended strongly that a publisher of an employee magazine not try to please everyone, but rather to "beam" the publication at the largest and most significant part of a heterogeneous audience (17). He pointed out that professional and management personnel often cultivated different tastes and expressed different needs from blue-collar workers, and therefore that management should "grit its teeth" and gear the publication toward the bulk of the audience-mechanics and operators (12).

Although the public relations department sought to provide a palatable publication for Du Pont employees, they specifically steered away from pandering to employee desires. Du Pont saw Better Living primarily as a means of top-down communication from corporate management to employees. Halley argued, employee periodicals could:

render maximum service to management. When it is no longer possible for leadership of an organization to physically meet people, the publication can serve as an artificial, but highly effective substitute. It enables a manager to insure that his people are kept informed, that they are experts who understand the meaning of the work they do, the process they operate, and the product they make. (12)

Employee feedback played absolutely no role in shaping the magazine's message. If management failed to exercise exclusive control over content, the magazine would not be "an instrument of persuasion at all, but an entertainment comparable to the employee recreation program" (Halley 18). Similarly, a report from the P. R. Department stated, "The publication's job[...] is not so much to give people what they like as to make them like what we have to give" (E. I. du Pont de Nemours). Thus, the 
magazine's editors did not report news and events. They produced interpretative pictorial essays that repeatedly stressed the points management wanted to convey. Most of the stories “covered" by Better Living consisted of obviously staged photographs of employees demonstrating good working conditions, abundant leisure time, high wages, and material comfort. Tellingly, Halley compared the job of an editor of an employee magazine to that of a director of a play, strategically determining such elements as cast, costume, set, props, and action to convey the point being made by a particular "picture story" (117-118). In making Better Living an instrument of persuasion, and not just an instrument for information and social reporting, the Du Pont communications program stood at the forefront of a wider postwar trend in employee communications. Concern about industrial journalism deteriorating into entertainment or "social reporting" at the expense of persuasion and interpretation pervaded the postwar professional literature on industrial journalism. C. J. Dover argued in the late 1950s, "the deterioration in public prestige of businessmen," "the emergence of union officials as one of the nation's most powerful, political groups," and "wage-cost inflation" made "the continued trend toward interpretative and persuasive content" in employee publications necessary and inevitable (13).

Although no reader reactions to Better Living have survived in the historical record to make a reception study of the magazine possible, according to reports from and independent studies contracted by the PR department, Better Living's editorial staff achieved a degree of success in reaching their target audience. No documents exist to demonstrate the magazine's direct and immediate impact on an employee's decisions to vote against unionization, support a particular political agenda, or purchase commodities. Undoubtedly few Du Pont employees would have consciously chosen to model their own thinking after the ideology professed by the magazine's editors; however, the evidence clearly demonstrates the company did manage to expose employees to the ideas in the magazine. In the late 1950s, Halley claimed that the magazine found its way into over 280 locations. Once inside the plants, employees apparently read the magazine. Halley cited an independent study commissioned to survey the magazine's circulation in the late 1950 s. $93 \%$ of the employees surveyed indicated that they "always" or "usually" read the publication. In addition, $86.8 \%$ of the total surveyed indicated that they read at least "a good part" of the magazine. Moreover, Better Living compared well with other magazines among the surveyed employees. $88 \%$ chose the magazine as one of their "favorites" from a list of contemporary periodicals, making Better Living the most widely chosen magazine on that list. Comparatively, only $56 \%$ of the same group listed the next most widely chosen periodical, Life magazine, among their "favorites." Perhaps explaining the magazine's popularity, a majority of the same group of employees chose "the company I work for and its people" from a long list of topics such as "home repair" and "hobbies" as the most important topic for a magazine to cover (Halley 33-34). Finally, citing the same survey in 1960, the trade journal Practical Public Relations noted that between three and four people viewed an average copy of Better Living. Members of the employee's family usually accounted for the extra readership (Untitled). Thus, employees found the magazine interesting and important enough to bring home from the plant to share with their families. 


\section{Better Than Ever... Improvements in Working-Class Life on the Pages of Better Living}

From the beginning of their publishing history, editors at Better Living wanted to let Du Pont employees know that they lived "better than ever," that as blue-collar workers at a large corporation in the postwar era, they enjoyed material lives and leisure time of which earlier generations of the American working class could not dream. To support that point, the editors repeatedly presented photo essays of Du Pont employees awash in consumer goods and engaged in recreational activities. As Harold Brayman argued in 1958

In our own employee magazine, no one could consistently, month after month, look at the pictures of our chemical operators, textile workers, machinists, truckers, winders, inspectresses, clerical workers - see them in their homes, their recreation and their work - and still believe that the American industrial employee is the downtrodden of the earth. (Brayman, "The Only Way" 7)

When he made the above pronouncement, Brayman could very well have been recalling a 1956 photo essay detailing the life of Norwood Tatman, an employee at the company's Edge Moor, Delaware plant, and his family in their new suburban home. The pictorial placed the Tatmans' move to the suburbs within the historical context of American workers' housing and the social context of the contemporary postwar suburban boom. The first two pages of the article featured a small four-panel display of drawings and stock photographs demonstrating meager workers' accommodations from frontier settlers" "crude log cabins" to the "crowded tenements" of turn-of-thecentury immigrants to multi-family dwellings in rural company towns. A much larger photograph of the Tatmans' "split level, 8-room house" stretched across the top of the page, lording over the small, crowded panel illustrations at the bottom. The size of the photograph emphasized the expansiveness of the Tatmans' new home, suggesting both freedom of movement and a sense of privacy for the family members silhouetted in its widely dispersed windows (see figure 2). The text and photographs on the remaining three pages continued to stress the roominess and comfort of the Tatmans' new home and to draw implicit and explicit comparisons with the historical working-class housing. Around title captions of "It's Great For Kids" and "New Homes Lighten the Housewife's Load" the article promoted a postwar family-centered suburban utopia. Six pictures of the Tatman children enjoying a birthday party, cleaning their rooms, riding bikes in the street, and frolicking on the front lawn with Dad illustrated the claim that "their parents [were] comforted in the thought that their children [were] growing up in a congenial neighborhood with better opportunities than they had." A series of pictures of Mrs. Tatman with accompanying captions argued that the space and electrical appliances in her new home reduced the time and effort she need to spend on ordinary chores, and that she could dedicate the time she saved to more fulfilling leisure and childrearing activities. Overall, the essay sought to demonstrate how the Tatmans, and the millions of other working-class Americans to which the article referred, had achieved a new level of comfort and convenience by purchasing a new suburban home away from the crowds, danger, and drudgery of the pre-war city ("The New Home"). 


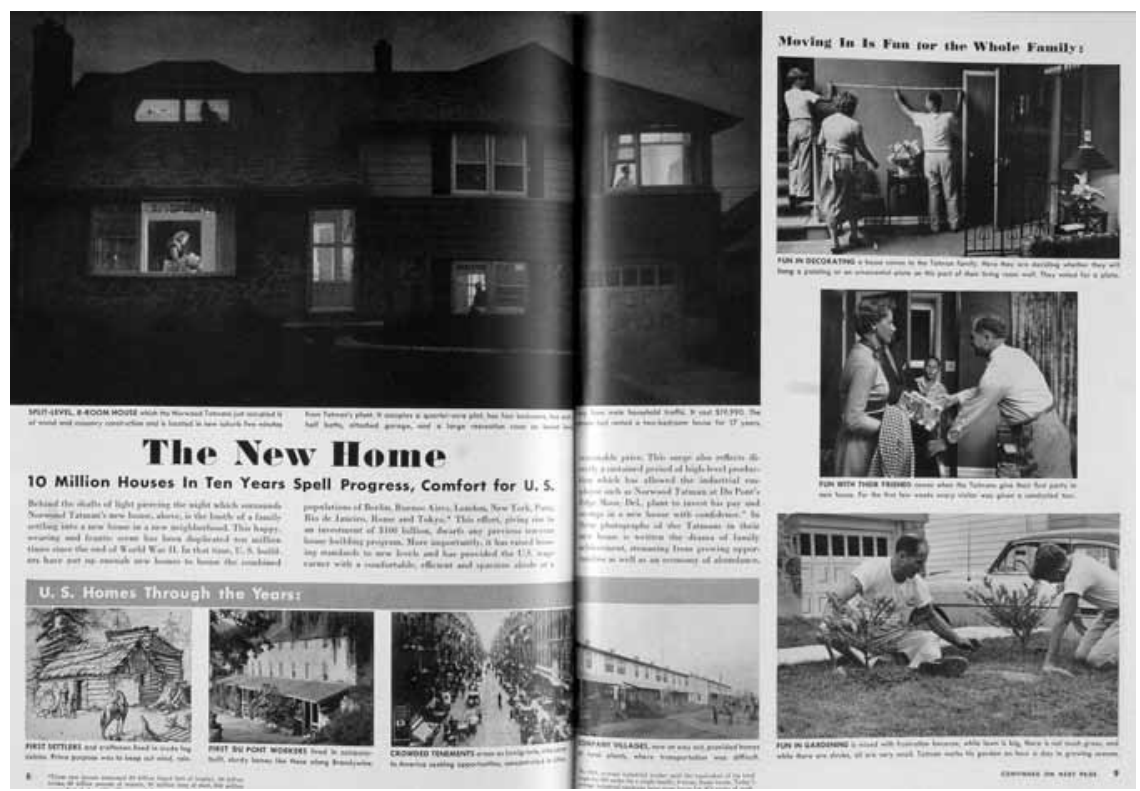

Figure 2. A depiction of a Du Pont family in their home from a 1956 issue of Better Living. Note the comparison with workers' housing in the illustrations and photos at the bottom. Courtesy of the Hagley Museum and Library, Wilmington, DE

Better Living relied on the vacation as its most frequent and graphic illustration of improvement in working-class lives. Employee holidays provided interesting locales and action scenes for photo opportunities, and additionally allowed the articles' text to point toward the company as the source with its liberal vacation plans and high wages. For example, "Vacations," pictured fifteen Du Pont employees enjoying or describing recent trips. Timed to come off the press in July at the beginning of the vacation season, the article pointedly asserted that many employees would soon be taking advantage of the company's recent liberalization of its vacation plan ("Vacations"). Moreover, the employee family holiday affirmed the nationalization of the Du Pont workforce, highlighting the shared experience of commercial leisure while downplaying workers' culture in plant communities. The magazine very rarely showed company-sponsored recreational events or events that attracted large numbers of workers. ${ }^{4}$ Almost invariably, the magazine depicted employees at play with members of the nuclear family. Better Living asked Du Pont workers to enjoy their leisure time, and the material abundance with which they filled it, not as a group of workers, but rather as the breadwinning heads of nuclear families. Those literal depictions of workers isolated from one another in their leisure time contrasted with the many group photographs of employees as members of company athletic teams, as co-workers celebrating shared experiences of company service, or simply as a clique of friends on vacation together that filled prewar employee publications (National Industrial Conference Board 33).

Not all of the magazine's pictorials focused on life outside the plant; a significant portion looked at improvements in blue-collar work itself. The magazine rarely 
focused on a particular employee's upward mobility to demonstrate progress in the work lives of working-class men. Rather, the editors highlighted the positive changes employees experienced while remaining at the same job for an extended period of time. Tellingly, even when the periodical profiled long-term employees who had achieved upward mobility, the editors quickly passed over individual advancement to tell a story of collective gain. For example, a 1950 article entitled "Man of the Half Century" examined progress in the life of Frank Gledhill since his birth in 1900. Gledhill had advanced from material checker to welding foreman during his twenty-nine year tenure with Du Pont. Rather than stress his job mobility, the article focused on the company-wide gains of reduced hours, less strenuous labor through automation, higher wages, and more generous benefits that Gledhill shared with all Du Pont employees. Discussions of working-class individuals as part of a collectively advancing industrial workforce contrasted with the magazine's family-centered depictions of working-class leisure; however, the magazine stopped short of crediting unions or working-class solidarity for acquiring these gains. Instead, the editors stressed the role of overall business growth, Du Pont profits, and company largesse in creating superior working conditions and compensation ("Man of the Half Century").

Moreover, the editors stressed improved working conditions and compensation, not as ends in and of themselves but as a path to a better material life. New work processes meant greater "efficiency" on the pages of Better Living, and greater efficiency meant more abundant, cheaper, and higher quality consumer goods. In addition, a higher rate of productive output per worker allowed the company to pay each individual worker higher wages. Finally, workers who produced more efficiently could work fewer hours per week at less strenuous jobs and still increase production. The end result meant both higher real wages - greater purchasing power per unit of time worked - and a relaxed yet energetic worker with plenty of leisure time to spend his pay. Better Living personified this concept of rising real wages in a profile of Ted Sheppard, a truck driver turned foreman at the Du Pont Parkersburg, West Virginia plant. In an article describing "Fifteen Years of Change" in Sheppard's life and the life of the nation, the editors chose to discuss increases in purchasing power between 1948 and 1963. Again, rather than the individual upward mobility Sheppard had experienced, the editors pointedly chose to examine a company-wide and national collective gain generated by economic growth.

\section{Better Than Anywhere Else... American Workers and Their International Counterparts on the Pages of Better Living}

In 1951 the journal Common Cause published an essay by the sociologist David Riesman called “The Nylon War." Riesman's essay took a satirical look at American consumer culture, while simultaneously noting the benefits it brought the average American citizen relative to the austerity in which much of the rest of the world lived. The titular "nylon war" was a fictional campaign mounted by the U.S. government to airdrop a bevy of American consumer goods into the Soviet Union. Women's nylon hosiery-made from that best known and most profitable Du Pont product — comprised the centerpiece of the aerial bombardment. According 
to Riesman's account, the nylon war met with great success. Uncontrollable demand for American consumer goods disrupted Soviet society and ultimately forced the Soviet Union to rededicate its productive power away from defense to consumer commodities. Despite a feeble counteroffensive by the Soviet Union - including a caviar airdrop over Idaho - the United States won Riesman's nylon war hands down.

"The Nylon War" presaged the great kitchen debate of 1959 between then vice president Richard Nixon and Soviet premier Nikita Khrushchev. Standing in the kitchen of a model American home at a Moscow fair, Nixon - demonstrating that truth could be at least as strange as Riesman's fiction - pointed to his surroundings as an example of America's unique capacity to produce and consume commodities. He then proceeded to berate Khrushchev over this concrete (or perhaps linoleum) example of the superiority of American capitalism to Soviet communism. Both Nixon and Riesman saw America's consumer economy as a more effective measure of America's place in the world and progress in the Cold War than military or diplomatic strength. Better Living printed dozens of photo essays that, like Riesman and Nixon, presented material abundance and consumer choice as fundamental components of American society and national identity.

At the height of the Cold War, Better Living frequently made the Soviet Union and its planned economy the whipping boy of a national identity based on a superior "American standard of living." The editors found particular pleasure in poking holes in supposed Soviet propaganda detailing the problems of the American working class. For example, a photograph of a perplexed Lewis Goff, a mechanic at Du Pont's Clinton, Iowa cellophane plant, pulling a newspaper out of his mailbox appeared on the back cover of a 1953 issue above a caption reading "Look What It Says About You." The text beneath explained that Goff held a copy of Pravda that reportedly argued that one-third of all Americans lived in poverty. If the large house in the background, presumably owned by Goff, did not adequately contradict the supposed Pravda report, then the remainder of the text underscoring the "concrete evidence" of American material abundance that all Americans could plainly see, certainly testified to the report's inaccuracy.

Until the federal government adopted the economist Mollie Orshansky's poverty thresholds in 1965, there was no official poverty measurement in the United States. Throughout the 1950s, scholars, labor organizations, and federal organizations developed and worked with competing poverty thresholds and rates (Fischer). Michael Harrington produced a good summary of this poverty literature in the appendix to The Other America, estimating that from 20 to $25 \%$ of the U.S. population - between 40 and 50 million individuals - lived in poverty in the late 1950s (190-194). Thus, to the editor's credit, Pravda did seem to overestimate American poverty figures. Yet, the choice to use a depiction of a single suburban home owned by one working family did not truly refute the fact that contemporary American social scientists counted millions of people who lived in poverty.

Like Nixon, the editors of Better Living sought to assuage fears about Soviet economic and military power by pointing to the widespread material abundance that characterized American society and the relative scarcity generated by the Soviet system. A characteristic opinion piece entitled "The Not-So-Secret Weapon" 
addressed the fear surrounding reports that the Soviets had successfully detonated an atomic warhead. Rather than deny the reports or call for a greater American nuclear buildup, the editor shifted his focus to what he saw as America's greatest advantage in the Cold War-the American standard of living.

Conceivably the Soviets do have the secret of atomic power [...] however, let us reflect that for some time they have also had the secret of the Chevrolet, and the Beautyrest, and the Chesterfield [...] Despite the fact that scientific data on these American achievements can be easily acquired, they haven't yet shown up in any quantity in Soviet Russia.

In this brief passage, the editor placated fears about Soviet military power, the arms race, and American espionage by demonstrating what he believed to be the true source of American national strength. Americans possessed the unique capability of developing products for the mass market, and that market - in the form of a national "living standard"-bound Americans together while separating the U.S. from the rest of the world's nations.

In addition to abstract editorial arguments about the superiority of the American market and living standard, Better Living also generated concrete comparisons of the United States and Soviet Union through pictorial essays of Du Pont employees. One of these pictorials, entitled "American Citizen," featured Alex Jasionowski, a Russian émigré and custodian at the Du Pont Parlin, New Jersey plant. The essay contrasted the "freedoms" and "rights" that Jasionowski enjoyed in the U.S. with the conditions he would have experienced if he had stayed in Russia. Although the pictorial did show Jasionowski in front of a church, a voting booth, and a newspaper stand to demonstrate the constitutionally guaranteed rights, the article gave much more weight to the material benefits Janiskowski and other American workers enjoyed over their Soviet counterparts. One such photograph showed Janiskowski waiting in line at a bank above a caption reading, "Alex cashes pay check at his bank. Purchasing power of U.S. worker has risen 50 per cent since 1928; Soviet worker's has dropped 50 per cent in same time." Other photographs featured his car, his adult daughter shopping in a well-stocked supermarket, and a row of suits in a men's clothing store (see figure 3). Another essay developed the same theme by photographing the family of Howard Eveland, a carpenter at the Edge Moor, Delaware plant, living as Soviet citizens for a day. As the essay stressed, the family discovered fundamental differences in the material living conditions of the two nations ("Penalties and Rewards"). By contrasting the purchasing power, the distribution of consumer durables, and consumer choice in the United States and the Soviet Union, these pictorials placed what the magazine called "standard of living" at the heart of the Cold War and American national identity.

While the magazine's pervading themes amount to a continuous implicit criticism of both international and domestic communism, editors avoided alarmist attacks on dangerous American subversives. Instead, they adopted the same tone of detached bemusement to discuss domestic communism that they used to discuss the Soviet Union. The American standard of living simply rendered the United States invul- 
nerable to communist subversion from within. For example, a 1950 editorial entitled "Come Da Revoloosh" presented Marxism as a vague, impressionistic set of ideas the lazy and shiftless adopted out of resentment for prosperous, hardworking Americans. In the editorial, the editor adopts a "regular guy" voice to report on a conversation he had with Chicago Slim, a bum with vaguely radical ideas, about how the world would look "come the revolution." Ultimately, despite the evidence of American workers eating well, living in comfortable homes, and driving nice cars in contemporary American society, Slim eagerly anticipated a revolution. Unfortunately, the only change that would come from Slim's revolution would be that lazy people would somehow enjoy the American standard of living while seizing authority and depriving the vast
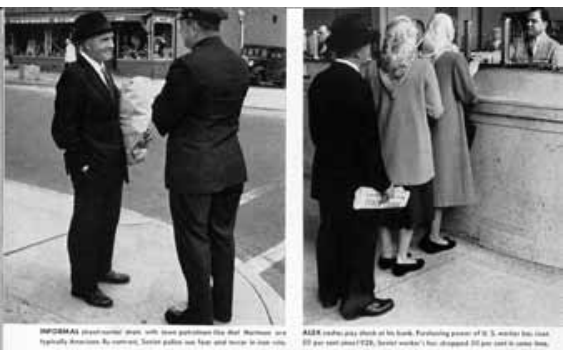

UNDER DEMOCRACY AMERICA OFFERS FREEOOM, RIGHTS TO ALL CITIZENS

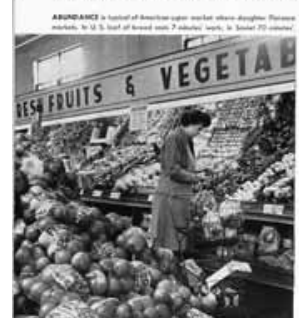

Figure 3. Alex Janiskowski enjoys the material benefits of being a U.S. citizen in a 1948 issue of Better Living. Courtesy of Hagley Museum and Library, Wilmington, DE. majority of the population of their current material comfort. The editorial disparaged Marxism for its authoritarianism and inability to provide materially while simultaneously personifying it in a character so laughable and so lazy that it ultimately posed no threat to an American society whose very identity depended on the material rewards of corporate capitalism.

Although many of the magazine's editorials and photo essays contrasted the American standard of living with the Soviet Union's, "better living" meant not only better than Russia, but as the editors asserted, "better than anywhere else." Therefore much of the magazine's content compared American material lives to the living conditions of people around the world. One editorial argued that even Great Britain's mild statism constrained individual freedom by forcing citizens to wait in line for goods and services. Hearkening back to American wartime scarcity, while simultaneously rejecting the idea of a need to sacrifice material wellbeing in the postwar world, the editor wrote,

During the war years, when we were under the stimulus of a united effort, things in queues went pretty well, even for us. [...] During the war it wasn't so bad. But when we think of lining up all the rest of our life for coupons for gasoline, for eggs, for permission to visit Atlantic City, or to go to a ball game, we are ready to scream.

In the postwar world Americans should enjoy the privilege, and even expect the right, of family vacations and commercialized leisure. Socialism asked the individual to sacrifice individual choice and immediate self-gratification for state 
planning that aimed at the good of the whole. Postwar Americans could not and should not be expected to make that sacrifice. In fact, the satisfaction of individual consumer desire itself blazed the path to public welfare, as it fueled the economic growth that led to greater material prosperity for all ("Line Up").

A photo essay from a 1951 issue entitled "Why We Eat Better" encapsulated the magazine's belief in the centrality of abundance and superior material conditions to American national identity. The pictorial also provides an excellent example of the magazine's method of developing a complex abstract argument through the strategic juxtaposition of simple photographs and illustrations. The essay featured a large photograph of Steve Czekalinski, his wife, and his two children surrounded by an enormous pile of food constituting a year's supply for the average American family of four. The photograph loomed over the entire top half of the first page and spread across most of the top of the second page, giving a sense of grand and overwhelming abundance. Five smaller duplicates of the original photo spread across the bottom of the first two pages beneath the larger original, each with a portion of the food from the original photo pointedly obscured. Each of the smaller photographs represented another of the world's countries - the United Kingdom, Belgium, West Germany, Poland, and China. The missing food represented the portion that the average family of each of these nations could not afford, based upon average hourly wages and prices of commodities in these countries. The material abundance literally spread out before the American worker in this photograph distinguished him and his family from the rest of the world's workers. His standard of living made him an American (see figure 4).

\section{The Path to Better Living: America's "Productive Capacity"}

According to the editorial stance at Better Living, workers needed to abandon any proclivity they might have for workplace industrial democracy or national social democracy if they wished to continue the pattern of continuing material progress and superiority. Their status depended on an abundance of inexpensive, quality material consumer goods, and only large-scale business enterprises could develop, produce, and market those goods efficiently enough to create that material bounty. Moreover, labor unrest and state regulation would drive up production costs and rob business of the competitive incentive to produce in the most efficient manner. Collective bargaining might increase wages in the short run, but it would ultimately reduce real wages by driving the costs of production to a level that would increase the prices of finished products workers purchased. As Better Living termed it, America's consumer society depended on American "productive capacity." Better Living demonstrated again and again that Du Pont and other large corporations produced the material abundance upon which Du Pont workers and America's working class thrived.

In a 1949 photo essay titled "New Products" the magazine offered a demonstration of how industrial chemical research, a process so capital intensive that only large corporations like Du Pont could undertake it, had paved the way for the progress in the American standard of living. The essay featured a large photograph of Elmer Downs - a tool grinder at the Bridgeport, Connecticut Remington Arms 


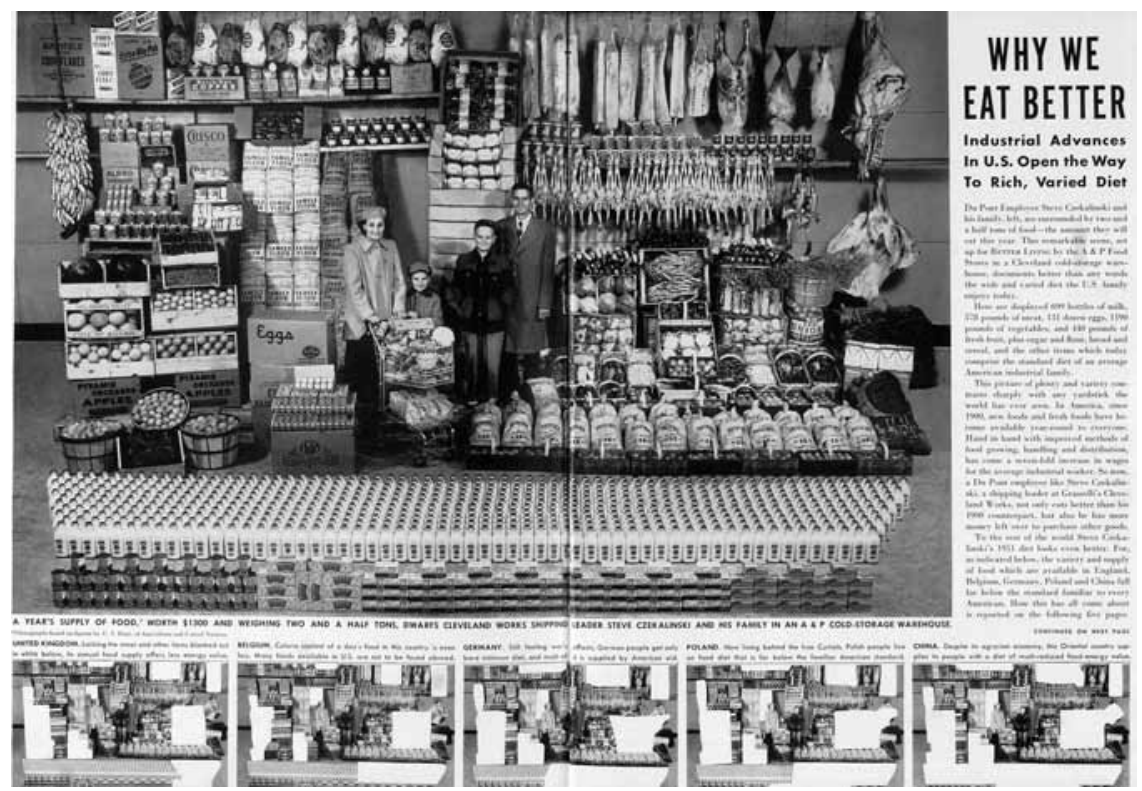

Figure 4. The Czekalinski family with a year's supply of food in a 1951 issue of Better Living.. The blank spots in the altered photos at the bottom represent the food typical working-class families in other nations would or could not obtain.

plant - and family surrounded by 24 labeled and identified products that Du Pont had developed over the previous twenty years. All the material accoutrements of the postwar good life were represented - automobile components, household appliances, toys, lawn and gardening equipment. Smaller photographs showed the family using many of these former "conveniences" that had now been unthinkingly integrated into American family life. The text of the essay informed the reader, "It is new products such as these, the offspring of chemical research, which have so enriched the American living standard over the past two decades" (17). Only a large-scale enterprise such as Du Pont could afford the overhead of research and development departments that helped to pioneer the postwar consumer's utopianew consumer goods made from synthetic materials.

According to Better Living, the pioneering efforts of industry had also developed efficient methods of production that made both novel and traditional products alike obtainable to the average American. More efficient production not only lowered prices, but also allowed businesses to pay each worker a higher wage by increasing the output of individual workers. Finally, efficient production meant easy work and shorter hours on the pages of Better Living. Therefore the average worker had more time and energy to spend his high wages on the fruits of American industry. The editors' favorite method of demonstrating industry's fundamentally important contribution to the rising standard of living was to measure decreases in the prices of a particular item in "real wages." For example, a photo essay titled "Why Your Clothes Cost Less," analyzed the findings of a National Industrial Conference Board study that uncovered a decrease in the real cost of clothing between 1914 and 
1948. The essay depicted Paul Resser, an operator from the Birmingham, Alabama explosives plant, along with his well-dressed family, modeling particular clothing items next to illustrations of comparable clothing items from 1914. A caption noted the number of hours Paul would have had to work to earn enough money for each item given the prevailing wage and price scales for 1914 and 1948. The essay also reproduced a chart that demonstrated changes in prices and wages over that period of time and offered the below analysis:

The chart above shows how the three-fold increase in clothing prices has been overshadowed by a six-fold increase in wages since 1914. But it cannot show why wages have increased so sharply. Through investments in better tools, industry has helped to make each job more productive.

Efficient production brought Du Pont workers better wages and better and more affordable goods upon which to spend them.

If national prosperity and the satisfaction of individual consumer dreams depended on efficient production by large-scale enterprise, then how could the individual and the nation made up of consuming individuals assist corporations to achieve maximum efficiency? Better Living linked consumer desire and depictions of the individual prosperity of Du Pont workers to larger social and economic processes. Labor unrest, inflationary cycles caused largely by public spending, and taxation all detracted from business's goal of producing as many goods as efficiently as possible. Individuals could make their contribution to shoring up the foundation of their own material lives, America's productive capacity, by contributing to labor peace, opposing government regulation and taxation of business, and by continuing to spend money to satisfy their desires.

Du Pont began printing Better Living in 1947 at the tail end of the strike wave that began during World War II and culminated with a protracted United Auto Workers strike against General Motors in 1946 and 1947. Throughout its 25 year run, the magazine dealt directly with the topic of labor unrest only once. In May of 1947, in an editorial analyzing the company's annual report from 1946, the editors pointed to the strike wave that had culminated during that year. The editor patted the company and its workers on the back for maintaining labor peace from the beginning of the war through 1946; however, the editorial argued that on a national level, labor unrest represented the most prominent threat to efficient production. Strikes threatened not only the companies that employed striking workers, but also the companies and workers that depended on striking industries as suppliers and purchasers. Du Pont operated within an integrated economic system, and therefore workers at Du Pont held an interest in maintaining labor peace throughout the nation ("Full Production"). Although the editors never again directly addressed the issue of labor peace, the entire magazine constituted a paean to the material rewards of loyal service to the company. The efficient production that resulted from cooperative workers, as evidenced on the pages of Better Living would lead to higher wages, more leisure time, easier work processes, and a material bounty that benefited everyone.

Unlike the tendency to dance around the topic of labor unrest, the magazine 
frequently and directly addressed the topic of taxes. The magazine's treatment of taxes, more than any other issue, exemplified the policy of making abstract arguments through concrete examples that demonstrated a problem's connection to the reader's individual self-interest. The magazine generally lumped all taxes - whether on sales, income, property or capital gains - into a single category. In fact, the editors argued that corporate taxes actually constituted "hidden" personal income taxes, because the consumer inevitably paid for them in the form of higher retail prices. A photo essay entitled "Taxes are Paid for in Lost Dreams," hammered home the point that corporate taxes actually constituted punitive "hidden taxes" on individual Du Pont workers. The essay showed Jeff Worral, an operator at the company's Carney's Point, New Jersey plant, posed with his wife and daughter amid the usual sea of consumer commodities. The editors priced each of the commodities in the photograph, adding them to a total of $\$ 7000$. The article noted that Worral had paid $\$ 7000$ in direct and hidden taxes over the previous six years. The goods scattered around him constituted the "lost dreams" for which his tax dollars could have paid (See figure 5). Thus, government regulation and taxation hindered efficient production and shackled the consumer. The editors argued that capital gains taxes, rather than redistributing wealth, actually robbed workers and consumers of a portion of their income.

\section{Manufacturing and Selling a New Conservatism at Du Pont}

Du Pont's joint employee/public relations campaign offers an excellent case study of the wider corporate response to the labor movement of the 1930s and 1940s and the resulting esteem in which much of the working public held the pro-union, pro-regulatory policies of labor liberalism. Even non-union employees of relatively non-union companies like Du Pont saw themselves as part of the labor culture, listened to the nationally-publicized pronouncements of such labor leaders as Walter Reuther and John L. Lewis, and exercised influence over state policy and the business climate. As the postwar employee communications guru Robert Newcomb argued in his 1951 advice manual for industrial editors, a "good editor [...] if his company is unionized [...] reads the union papers. If it isn't organized, he reads union papers anyway. He considers it part of his job to know what unions tell their people" (103). Indeed, because the New Deal and the emergence of industrial unionism had politically mobilized so many American workers, public relations staff at Du Pont and other U.S. companies spoke to employees as a public whose concerns and power both transcended and shaped their relationships with their employers.

Management at Du Pont and other American corporations in the postwar era attempted to "sell free enterprise" to their workers as Elizabeth Fones-Wolf has argued; however, they went beyond merely assaulting unions and reaffirming the ideology of individualistic, competitive capitalism. They also sold a vision of an ideal America - one that offered corporate benevolence and individual material rewards in exchange for loyalty to their employer and American corporate capitalism. Rather than a nation of entrepreneurs, Better Living envisioned a nation of consumer citizens, committed to working and spending together for greater 


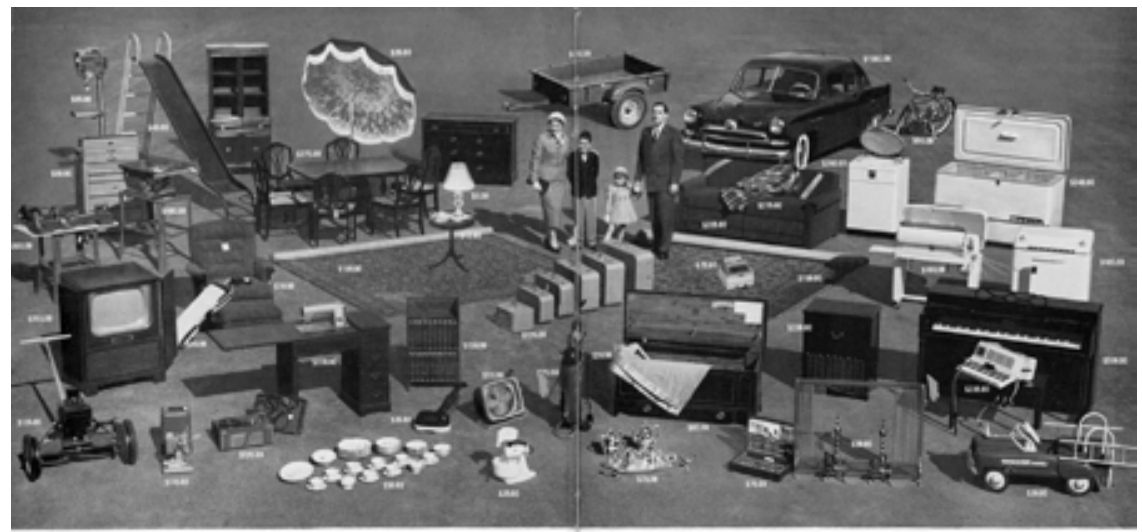

\section{TAXES ARE PAID IN LOST DREAMS}
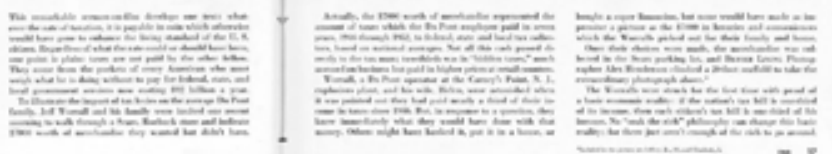

Figure 5. A 1953 issue of Better Living features a working family and the plethora of consumer goods they were forced to forgo due to taxes. Better Living lumped together income taxes, sales taxes, and the "hidden taxes" workers paid in the form of inflated prices.

production, material abundance, and national progress.

In selling Du Pont employees a vision of "better living," based on the enjoyment of a material prosperity that could only be generated by unregulated capitalism, the company's Public Relations department pioneered a conservative message new to the postwar era. First, Du Pont management spoke to their employees as a "public" with broad political concerns and influence, not simply as an internal audience. In addition, their message focused on the positive aspects of American life that this employee public had attained and would continue to enjoy, rather than simply criticizing the role of unions in the workplace. In these ways, the new conservatism of the postwar era differed from pre-war corporate campaigns. In those campaigns, employers spoke to their workforce exclusively as employees, focused on internal workplace issues, and publicized how the paternal hand of the company protected workers better than union outsiders. Pre-war employers reserved broader theoretical and political discussions for a middle-class public that never passed through the factory gate.

This was a visually and emotionally appealing new conservative ideology, one that had become ascendant by the $1980 \mathrm{~s}$ and one that has persisted into the $21^{\text {st }}$ century. Opposition to taxation and state regulation is at the heart of recent American conservatism. Conservatives condemn state efforts to regulate the economy because they create macroeconomic inefficiencies and because they hurt the economic and material lives of individual citizens. Much of that conservative message, which links individual material self-interest to a deregulated capitalist economy, can be traced to the efforts of postwar employers to speak to and define their employee public. Good working-class citizens worked (though not nearly as hard as their ancestors), rejected the pronouncements of labor leaders and tax-and-spend politi- 
cians, and remained loyal to their employer and corporate capitalism. In exchange, they would be rewarded with the better things for better living that only unbridled capital could produce.

\section{Notes}

${ }^{1}$ For the popular origins of contemporary conservatism see Formisano, Boston Against Bussing; Carter, The Politics of Rage; McGirr, Suburban Warriors; Critchlow, Phylis Schlafly and Grassroots Conservatism. See Witwer, "Westbrook Pegler and the Anti-union Movement," and Philips-Fein, "American Counterrevolutionary" for two studies that look at conservative ideas at the elite level.

${ }^{2}$ The definitive interpretation of the reorganization of Du Pont and the company's critical role in developing the modern corporation is Chandler and Salsbury, Pierre S. du Pont and the Making of the Modern Corporation. See also Chandler, Strategy and Structure.

3 For two contemporary analyses of prewar employee publications that note a lack of overt discussion of political and economic matters see Flexner, "Selling the Company," and National Industrial Conference Board, Employee Magazines in the United States.

${ }^{4}$ I thoroughly surveyed every issue of Better Living and found only two such pictorials, one showing a company-wide bowling tournament and the other a raccoon hunt and barbecue attended by a large number of employees at the Old Hickory, Tennessee rayon plant. See "Bowlers," BL 3 (November/December 1949): 14-15 and "Coon Hunt," BL 4 (March/April 1950): 30-2.

\section{Works Cited}

“American Citizen." Better Living 2 (September/October 1948): 13-17.

Bird, William L. Better Living: Advertising, Media, and the New Vocabulary of Business Leadership, 1935-1955. Evanston, IL: Northwestern University Press, 1999.

"Bowlers." Better Living 3 (November/December 1949): 14-15.

Brayman, Harold. "Du Pont Public Relations Department." 1958. Hagley Library, Wilmington, Delaware.

---. “The Only Way." Public Relations Journal 5 (July 1949): 4-9, +.

Carter, Dan T. The Politics of Rage: George Wallace, the Origins of the New Conservatism, and the Transformation of American Politics. Baton Rouge: Louisiana State University Press, 1996.

Chandler, Alfred D. Strategy and Structure: Chapters in the History of Industrial Enterprise. Cambridge, MA: MIT Press, 1962.

---, and Stephen Salsbury. Pierre S. Du Pont and the Making of the Modern Corporation. New York: Harper and Row, 1971.

Cohen, Lizabeth. A Consumers' Republic: The Politics of Mass Consumption in Postwar America. New York: Alfred A. Knopf, 2003.

"Come da Revoloosh." Better Living 4 (January/February 1950): editorial page.

"Coon Hunt," Better Living 4 (March/April 1950): 30-2.

Critchlow, Donald T. Phylis Schlafly and Grassroots Conservatism: A Woman's Crusade. Princeton, NJ: Princeton University Press, 2005. 
Dover, C. J. Effective Communication in Company Publications. Washington, DC: BNA, Inc., 1959.

E.I. du Pont de Nemours and Co., Public Relations Department. "Getting the Most from Your Plant Publication.” 1956. Hagley Library, Wilmington, DE.

Fischer, Gordon M. "From Hunter to Orshansky: An Overview of (Unofficial) Poverty Lines in the United States from 1904 to 1965." Poverty Measurement Working Papers, 1997. < http://www.census.gov/hhes/www/povmeas/papers/ hstorsp4.html >

Flexner, Jean Atherton. "Selling the Company." New Republic 9 April 1924: 171-174. Fones-Wolf, Elizabeth. Selling Free Enterprise: The Business Assault on Labor and Liberalism, 1945-1960. Urbana: University of Illinois Press, 1994.

Formisano, Ronald P. Boston Against Bussing: Race, Class, and Ethnicity in the 1960s and 1970s. Chapel Hill: University of North Carolina Press, 1991.

"Full Production." Better Living 1 (May 1947): editorial page.

Genzer, Nancy Marshall. "Working the Vote." Marketplace. Natl. Public Radio. 26 October 2006. Transcript. < http://marketplace.publicradio.org/display/ web/2006/10/26/working_the_vote $>$.

Halley, William C. Employee Publications: Theory and Practice of Communications in the Modern Organization. Philadelphia: Chilton Company, 1959.

Harrington, Michael. The Other America: Poverty in the United States. New York: The Macmillan Company, 1962.

Harris, Howell John. The Right to Manage: Industrial Relations Policies of American Business in the 1940s. Madison: The University of Wisconsin Press, 1982.

Hounshell, David and John Kenly Smith, Jr. Science and Corporate Strategy: Du Pont $R \&$ \& , 1902-1980. New York: Cambridge University Press, 1988.

Jacoby, Sanford. Modern Manors: Welfare Capitalism since the New Deal. Princeton, NJ: Princeton University Press, 1997.

"Line up over Here." Better Living 4 (September/October 1950): editorial page.

"Look What It Says about You." Better Living 7 (May/June, 1953): back cover.

McGirr, Lisa. Suburban Warriors: The Origins of the New American Right. Princeton, NJ: Princeton University Press, 2001.

"Man of the Half Century." Better Living 4 (July/August 1950): 6.

National Industrial Conference Board. Employee Magazines in the United States. New York: National Industrial Conference Board, 1925.

“The New Home." Better Living 10 (January/February 1956): 8-13.

"New Products." Better Living 3 (January/February 1950): editorial page.

Newcomb, Robert, and Marg Sammons. Employee Communications in Action. New York: Harper and Brothers Publishers, 1961.

---. Speak Up, Management! How to Communicate with Employees and Public. New York: Funk \& Wagnalls Company, 1951.

“The Not-So-Secret Weapon.” Better Living 2 (November/December 1949): editorial page.

"Penalties and Rewards." Better Living 6 (November/December 1952): 2-9.

Phelan, James and Robert Pozen. The Company State: Ralph Nader's Study Group Report on Du Pont in Delaware. New York: Grossman Publishers, 1973. 
Phillips-Fein, Kimberly. "American Counterrevolutionary: Lemuel Ricketts Boulware and General Electric, 1950-1960." American Capitalism: Social Thought and Political Economy in the Twentieth Century. Ed. Nelson Lichtenstein. Philadelphia: University of Pennsylvania Press, 2006. 249-270.

---. Invisible Hands: The Making of the Conservative Movement from the New Deal to Reagan. New York: W.W. Norton \& Company, 2009.

Press release (untitled). 6 December 1946. Du Pont Public Affairs Department Records, Box 36, Hagley Library, Wilmington, DE.

"Prosperity Project." Business Industry Political Action Committee. 2009. <http:// www.bipac.org/page.asp?g=BIPAC_PUBLIC\&content=services-prosperityproject>.

Riesman, David "The Nylon War." Common Cause 4 (1951): 379-385. Rpt. in Abundance for What? And Other Essays. Garden City, NY: Doubleday and Company, 1964. 67-79.

Stone, William. "The Munitions Industry: An Analysis of the Senate Investigation." Foreign Policy Reports 10 (No. 20, December 5, 1934).

“Taxes are Paid for in Lost Dreams.” Better Living 8 (May/June 1953): 16-17.

Untitled article in Practical Public Relations 10 (October 1960): 5.

"Vacations." Better Living 1 (July 1947): 17-18.

"What Is 'Better Living?"' Better Living 1 (July, 1947), inside cover.

"Why We Eat Better." Better Living 5 (November/December 1951): 2-8.

"Why your Clothes Cost Less." Better Living 2 (January/February 1948): 4-6.

Wilz, John E. In Search of Peace: The Senate Munitions Inquiry, 1934-1936. Baton Rouge: Louisiana State University Press, 1963. 
78 IJCS 